\title{
Cytotaxonomy and karyology of the tribe Otiorhynchini (Coleoptera: Curculionidae)
}

\author{
Dorota LACHOWSKA ${ }^{1}$, Maria ROŻEK ${ }^{1}$ and Milada HOLECOVÁ2 \\ ${ }^{1}$ Institute of Systematics and Evolution of Animals, Polish Academy of Science, Sławkowska 17, 31-016 Kraków, Poland; \\ e-mail: lachowska@isez.pan.krakow.pl \\ ${ }^{2}$ Department of Zoology, Comenius University, Mlynská dolina B-1, 842-15 Bratislava, Slovakia
}

Key words. C-banding, chromosome number, Coleoptera, Curculionidae, fluorochrome staining, karyotype, NORs, taxonomy

\begin{abstract}
A cytogenetic study of bisexual species belonging to the genera Cirrorhynchus, Dodecastichus and Otiorhynchus is presented in order to confirm their taxonomic position. The karyotype characterization was accomplished by an analysis of mitotic and meiotic chromosomes after differential staining, namely by C-banding, silver impregnation, DAPI and $\mathrm{CMA}_{3}$. A review of the cytogenetic data for the tribe Otiorhynchini contributed to knowledge of chromosomal evolution in this group. An investigation of five of the species studied showed some similarities such as a sex chromosome system of "parachute type" $\left(\mathrm{Xy}_{\mathrm{p}}\right)$, the presence of 10 autosomal bivalents $(2 n=22)$ and heterochromatin localized around centromeres. These observations are similar to those already described for Otiorhynchini species, and confirm the karyological conservatism of this weevil group. In contrast, another species Cirrorhynchus kelecsenyi has an additional four autosomal bivalents ( $\mathrm{o} \hat{=}=14+\mathrm{Xy}_{\mathrm{p}}, 2 \mathrm{n}=30$ ), which differs considerably from the chromosomal homogeneity of the other genera. Karyotypic evolution in this species was achieved most probably by increasing the number of chromosomes by centric fissions, resulting in variation in the number of acrocentric chromosomes. DAPI-positive and $\mathrm{CMA}_{3}$-negative reactions of heterochromatic DNA in all the species studied suggest that it has an AT-rich composition. Impregnating chromosomes with silver nitrate reveals NORs on one pair of autosomes, and probably argentophilic material in the interspace between the $\mathrm{X}$ and y sex chromosomes. The karyological findings support the taxonomical revision of Otiorhynchini based on morphological characters.
\end{abstract}

\section{INTRODUCTION}

The Curculionidae is one of the largest beetle families with some 50,000 described species (Lawrence \& Newton, 1995). So far, the karyology of about 600 species of Curculionidae has been investigated, although the great majority of the cytogenetic findings reported for weevils only refer to male chromosome numbers and sex determination system at meiotic metaphase I. Much less research has focused on the banded karyotypes of curculionids (Hsiao \& Hsiao, 1984; Holecová et al., 2002; Rożek et al., 2004; Lachowska et al., 2004, 2005, 2006a, b). Data on the karyology of Curculionidae varies greatly from genus to genus and from subfamily to subfamily. There are many species-rich genera in which chromosomal composition has not yet been determined.

The tribe Otiorhynchini comprises ten genera (Cirrorhynchus, Dodecastichus, Limatogaster, Otiorhynchus, Neotournieria, Parameira, Parotiorhynchus, Rhynchotious, Solariola, and Tylotus) autochthonous exclusively to the Palaearctic region (Magnano, 1998). Only ten species of Otiorhynchus have been introduced into North America. Adults are generalists, feeding on various plants, whereas larvae are root-eating. Numerous species are apterous, characterized by nocturnal activity (Arnoldi, 1975; Dieckmann, 1980; Smreczyński, 1966). This group of weevils is well known for having a large number of parthenogenetic lineages, which have a much broader distribution than their sexual counterparts (Suomalainen et al., 1987). The Otiorhynchus-complex comprises about
1,500 species and is not only the largest and most speciose group within the Curculionidae, but also among taxons of higher rank (e.g. subgenera and species groups). The systematics of the Otiorhynchus-complex has been controversial for a long time. According to systems proposed by Stierlin (1883), Reitter (1916), Penecke (1935) and Arnoldi (1975), the genus Otiorhynchus should be divided into several subgenera and groups of species. The latest system of Magnano (1998) is the result of more than twenty years of studying Otiorhynchus and related genera. According to this author the Otiorhynchuscomplex comprises eight separate genera: Dodecastichus Stierlin, 1861; Cirrorhynchus Apfelbeck, 1898; Limatogaster Apfelbeck, 1899; Otiorhynchus Germar, 1824; Neotournieria Apfelbeck, 1832; Parotiorhynchus Magnano, 1998; Rhynchotious Magnano, 1998; Tylotus Schönherr, 1823. The largest genus Otiorhynchus is divided into 105 subgenera (Magnano, 1998). At present, studies on the systematics and phylogeny of beetles are based on morphological, as well as on genetic and cytogenetic data (Angus et al., 2000; Gomez-Zurita et al., 2004; Petitpierre et al., 2004; Dutton \& Angus, 2007). So far 34 bisexual species and 18 parthenogenetic species or races of the tribe Otiorhynchini from central and northern Europe, the Balkan Peninsula, and Sicily have been karyologically studied (Suomalainen, 1947; Smith \& Virkki, 1978; Mikulska, 1951, 1960; Tucić \& Mesaroš, 1992; Holecová et al., 1997a, b; Lachowska et al., 1998; Lachowska \& Holecová, 2000; Holecová et al., 2002). 
TABLE 1. Species of weevils whose karyotype was determined.

\begin{tabular}{|c|c|}
\hline Species & Geographic source and date of collection \\
\hline Cirrorhynchus kelecsenyi Frivaldszky, 1892 & $\begin{array}{l}\left.\text { C Slovakia, Strážovské vrchy Mts., Zliechov ( } 48^{\circ} 56^{\prime} \mathrm{N}, 18^{\circ} 26^{\prime} \mathrm{E}\right) \text {, June } \\
9,2006\end{array}$ \\
\hline Dodecastichus inflatus (Gyllenhal, 1834) & $\begin{array}{l}\text { SW Slovakia, Malé Karpaty Mts, Pezinská Baba hill }\left(48^{\circ} 21^{\prime} \mathrm{N} \text {, }\right. \\
\left.17^{\circ} 11^{\prime} \mathrm{E}\right) \text {, May } 19,2006\end{array}$ \\
\hline $\begin{array}{l}\text { Otiorhynchus (s. str.) coecus Germar, } 1824 \\
=\text { niger (Fabricius, 1775) }\end{array}$ & $\begin{array}{l}\text { C Slovakia, Strážovské vrchy Mts, Strážov Nature Reserve }\left(48^{\circ} 57^{\prime} \mathrm{N} \text {, }\right. \\
\left.18^{\circ} 28^{\prime} \mathrm{E}\right) \text {, June } 9,2006\end{array}$ \\
\hline $\begin{array}{l}\text { Otiorhynchus (s. str.) cornicinus Stierlin, } 1861 \\
=\text { laevigatus (Fabricius, 1792) }\end{array}$ & $\begin{array}{l}\text { C Slovakia, Zvolenská kotlina basin, Jakub-Roháčovo }\left(48^{\circ} 46^{\prime} \mathrm{N} \text {, }\right. \\
\left.19^{\circ} 08^{\prime} \mathrm{E}\right) \text {, May } 26,2006\end{array}$ \\
\hline Otiorhynchus (s. str.) multipunctatus (Fabricius, 1792) & $\begin{array}{l}\text { C Slovakia, Strážovské vrchy Mts, Zliechov ( } 48^{\circ} 56^{\prime} \mathrm{N}, 18^{\circ} 26^{\prime} \text { E), June } \\
9,2006\end{array}$ \\
\hline Otiorhynchus (Phalantorrhynchus) morio (Fabricius, 1781) & $\begin{array}{l}\text { C Slovakia, Strážovské vrchy Mts, Strážov Nature Reserve ( } 48^{\circ} 57^{\prime} \mathrm{N} \text {, } \\
\left.18^{\circ} 28^{\prime} \mathrm{E}\right) \text {, June } 9,2006\end{array}$ \\
\hline
\end{tabular}

The present paper is a continuation of research on the karyology of Palaearctic weevils. The aim of this study is: (1) to provide more information on the chromosomes of bisexual species of Otiorhynchini- and determine whether an ancestral karyotype ( $\mathrm{c} \hat{\sigma}=10+\mathrm{Xy}_{\mathrm{p}}$ ), characteristic for most weevils, predominates in the analysed group; (2) to characterize karyotypic diversity in six species belonging to three genera (Cirrorhynchus, Dodecastichus and Otiorhynchus) using differential chromosome banding tech- niques; (3) to compare the chromosomal results and the taxonomical position of Cirrorhynchus kelecsenyi.

\section{MATERIAL AND METHODS}

Adults of both sexes were collected in Slovakia in May and June 2006 (Table 1). Voucher specimens are deposited in the Institute of Systematics and Evolution of Animals PAS, Kraków, Poland. Gonads (9-10 from each species) were dissected under a stereomicroscope in several drops of hypotonic $0.9 \%$ sodium citrate solution containing $0.005 \%$ colchicine. The

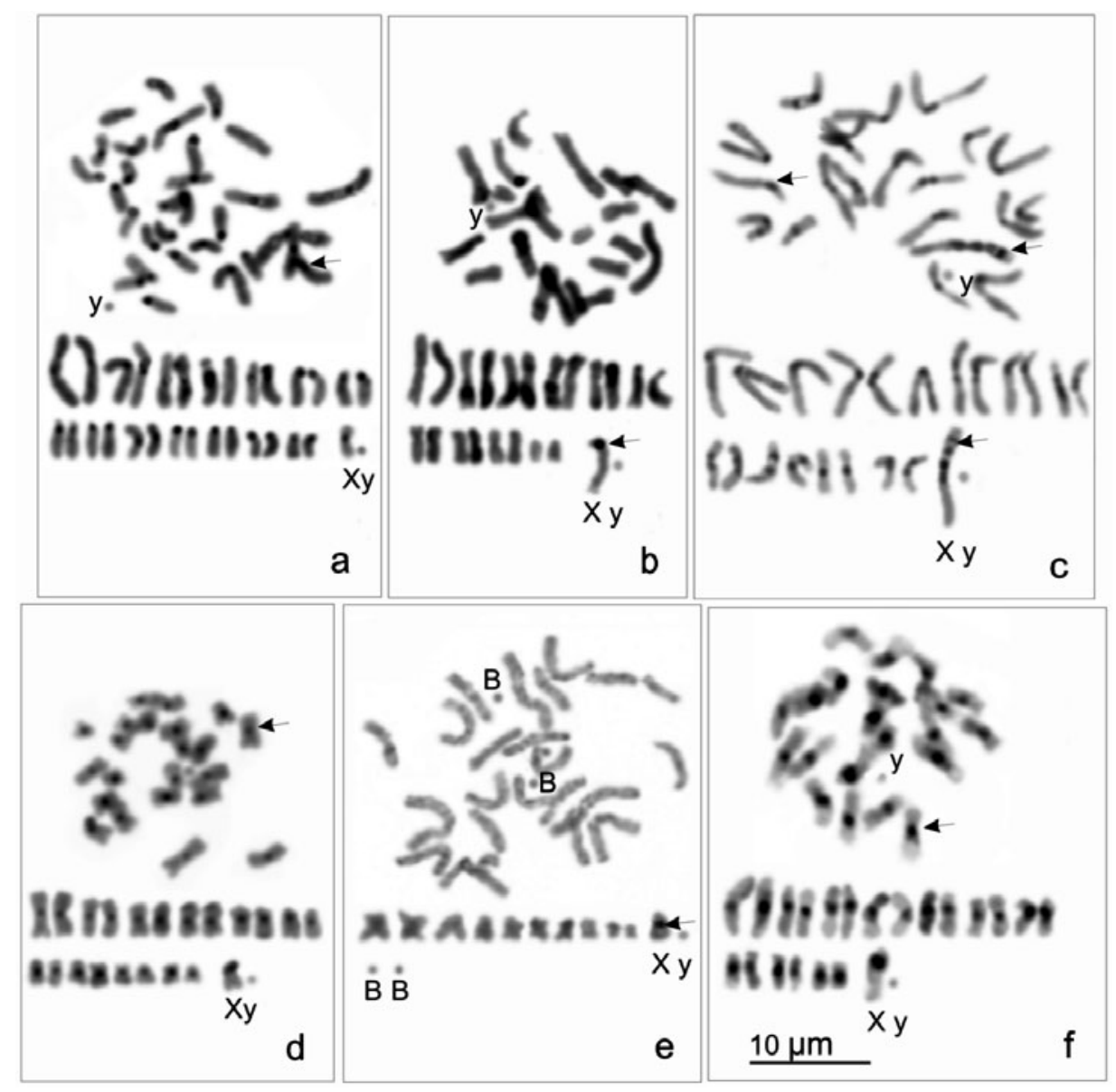

Fig. 1. C-band staining of the chromosomes at mitotic metaphase in: a - Cirrorhynchus kelecsenyi; b - Dodecastichus inflatus; c - Otiorhynchus coecus; d - Otiorhynchus cornicinus; e - Otiorhynchus multipunctatus; f - Otiorhynchus morio. Arrows indicate C-bands; X, y - sex chromosomes; B - supernumerary chromosome. 
TABLE 2. Chromosome numbers of the species studied and their relative lengths (\% TCL), and the centromeric index (AR) of particular chromosome pairs.

\begin{tabular}{|c|c|c|c|c|c|c|}
\hline \multirow[t]{2}{*}{ Pair no. } & \multicolumn{2}{|c|}{ 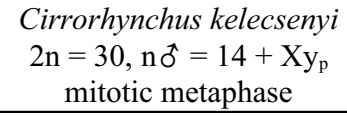 } & \multicolumn{2}{|c|}{$\begin{array}{c}\text { Dodecastichus inflatus } \\
2 \mathrm{n}=22, \mathrm{n} \widehat{\widehat{ }}=10+\mathrm{Xy}_{\mathrm{p}} \\
\text { mitotic metaphase }\end{array}$} & \multicolumn{2}{|c|}{$\begin{array}{l}\text { Otiorhynchus coecus } \\
2 \mathrm{n}=22, \mathrm{n} \widehat{\widehat{0}}=10+\mathrm{X}_{\mathrm{p}} \\
\text { mitotic metaphase }\end{array}$} \\
\hline & $\% \mathrm{TCL}$ & $\mathrm{AR}$ & $\% \mathrm{TCL}$ & $\mathrm{AR}$ & $\%$ TCL & $\mathrm{AR}$ \\
\hline 1 & 12.30 & 1.87 & 13.43 & 1.01 & 12.52 & 1.40 \\
\hline 2 & 11.03 & 1.29 & 11.22 & 1.27 & 11.74 & 1.14 \\
\hline 3 & 8.48 & 1.01 & 11.99 & 1.42 & 10.02 & 1.27 \\
\hline 4 & 7.40 & 4.91 & 10.12 & 1.44 & 9.61 & 1.40 \\
\hline 5 & 6.58 & 1.82 & 8.71 & 1.12 & 8.41 & 3.10 \\
\hline 6 & 6.46 & 3.32 & 8.68 & 5.05 & 7.55 & 1.37 \\
\hline 7 & 6.22 & 3.27 & 6.86 & 1.66 & 7.23 & 1.21 \\
\hline 8 & 6.05 & 3.23 & 6.44 & 1.30 & 6.85 & 1.61 \\
\hline 9 & 5.68 & - & 6.40 & 1.32 & 6.79 & 1.08 \\
\hline 10 & 5.47 & 1.47 & 4.16 & - & 6.10 & 1.27 \\
\hline 11 & 4.98 & 3.63 & - & - & - & - \\
\hline 12 & 4.72 & - & - & - & - & - \\
\hline 13 & 4.32 & 3.06 & - & - & - & - \\
\hline 14 & 4.18 & 3.01 & - & - & - & - \\
\hline $\mathrm{X}$ & 5.02 & 1.51 & 10.67 & 4.17 & 11.95 & 1.24 \\
\hline $\mathrm{y}$ & 1.11 & - & 1.42 & - & 1.24 & - \\
\hline \multirow[t]{2}{*}{ Pair no. } & \multicolumn{2}{|c|}{$\begin{array}{l}\text { Otiorhynchus cornicinus } \\
2 \mathrm{n}=22, \mathrm{n}{ }^{\hat{x}}=10+\mathrm{Xy}_{\mathrm{p}} \\
\text { mitotic metaphase }\end{array}$} & \multicolumn{2}{|c|}{$\begin{array}{c}\text { Otiorhynchus multipunctatus } \\
2 \mathrm{n}=22+1-2, \mathrm{n} \widehat{\widehat{O}}=10+\mathrm{Xy}_{\mathrm{p}}+1-2 \mathrm{~B} \\
\text { metaphase II }\end{array}$} & \multicolumn{2}{|c|}{$\begin{array}{c}\text { Otiorhynchus morio } \\
2 \mathrm{n}=22, \mathrm{n} \widehat{\delta}=10+\mathrm{Xy}_{\mathrm{p}} \\
\text { mitotic metaphase }\end{array}$} \\
\hline & $\% \mathrm{TCL}$ & $\mathrm{AR}$ & $\% \mathrm{TCL}$ & $\mathrm{AR}$ & $\% \mathrm{TCL}$ & $\mathrm{AR}$ \\
\hline 1 & 12.97 & 1.14 & 11.55 & 1.26 & 13.50 & 1.15 \\
\hline 2 & 11.16 & 1.10 & 10.61 & 1.05 & 11.27 & 1.21 \\
\hline 3 & 10.13 & 1.02 & 10.52 & 1.35 & 10.80 & 1.52 \\
\hline 4 & 9.81 & 1.18 & 8.82 & 1.80 & 9.68 & 1.26 \\
\hline 5 & 9.38 & 1.35 & 8.42 & 1.15 & 9.31 & 1.18 \\
\hline 6 & 9.10 & 1.40 & 8.40 & 1.16 & 7.87 & 1.08 \\
\hline 7 & 8.25 & 1.20 & 7.38 & 1.10 & 7.45 & 1.17 \\
\hline 8 & 6.94 & 1.21 & 7.32 & 1.12 & 6.93 & 1.42 \\
\hline 9 & 5.87 & 1.51 & 6.31 & 1.07 & 6.80 & 1.20 \\
\hline 10 & 5.63 & 1.06 & 5.08 & 1.11 & 4.85 & 1.14 \\
\hline $\mathrm{X}$ & 8.69 & 1.45 & 10.61 & 1.78 & 9.76 & 1.16 \\
\hline $\mathrm{y}$ & 2.06 & - & 1.67 & - & 1.72 & - \\
\hline $2 \mathrm{~B}$ & - & - & 3.04 & - & - & - \\
\hline
\end{tabular}

gonads were transferred into a small volume of the same solution and incubated for 30-45 $\mathrm{min}$ at room temperature. Then the gonads were fixed according to the method described by Rożek (1994) with a minor modification (Rożek \& Lachowska, 2001). C-banding was performed using the procedure described by Sumner (1972) with some modifications (Lachowska et al., 2006a). The slides were stained with $4 \%$ Giemsa in phosphate buffer (pH 6.8) for 10 to $20 \mathrm{~min}$. For NOR silver staining the method described by Howell \& Black (1980) was used with some modifications (Lachowska et al., 2005). The DNA binding fluorochromes, GC-specific chromomycin $\mathrm{A}_{3}\left(\mathrm{CMA}_{3}\right)$ and AT-specific 4'-6-diamidino-2-phenylindole (DAPI), were used according to the methods described by Schweizer (1976) and Donlon \& Magenis (1983), with minor modifications. The slides were first subjected to the $\mathrm{C}$-banding procedure and, to improve the fluorochrome staining, $0.5 \%$ methanol was included in the fluorescent dye. After staining, the slides were mounted in antifade medium consisting of $1 \% \mathrm{n}$-propylgallate in a $10 \mathrm{M}$ phosphate buffer solution with $70 \%$ glycerol at $\mathrm{pH} 7.0$. Evaluation of chromosome morphology was based on ten mitotic metaphases.
In order to facilitate the arrangements of karyograms, the chromosome lengths were calculated as percentages of the total chromosome length of the haploid set (\% TCL), which also includes the sex chromosomes. Chromosomes were classified according to Levan et al. (1964). Spermatogonial metaphase, meiotic stages, and interphase nuclei were analyzed and photographed using a Nikon Eclipse 400 light microscope and CCD DS-U1 camera (Nikon, Tokyo, Japan) and the software Lucia Image, version 5.0 (Laboratory Imaging, Prague, Czech Republic).

\section{RESULTS}

Herein, we report chromosomal findings for six bisexual species of which two are new records for the cytogenetic knowledge of the tribe, with the aim to discuss the trends in chromosome evolution in Otiorhynchini. Five of the species show some similarities such as a sex chromosome system of achiasmatic parachute type $\left(\mathrm{Xy}_{\mathrm{p}}\right)$ and presence of 10 autosomal bivalents 


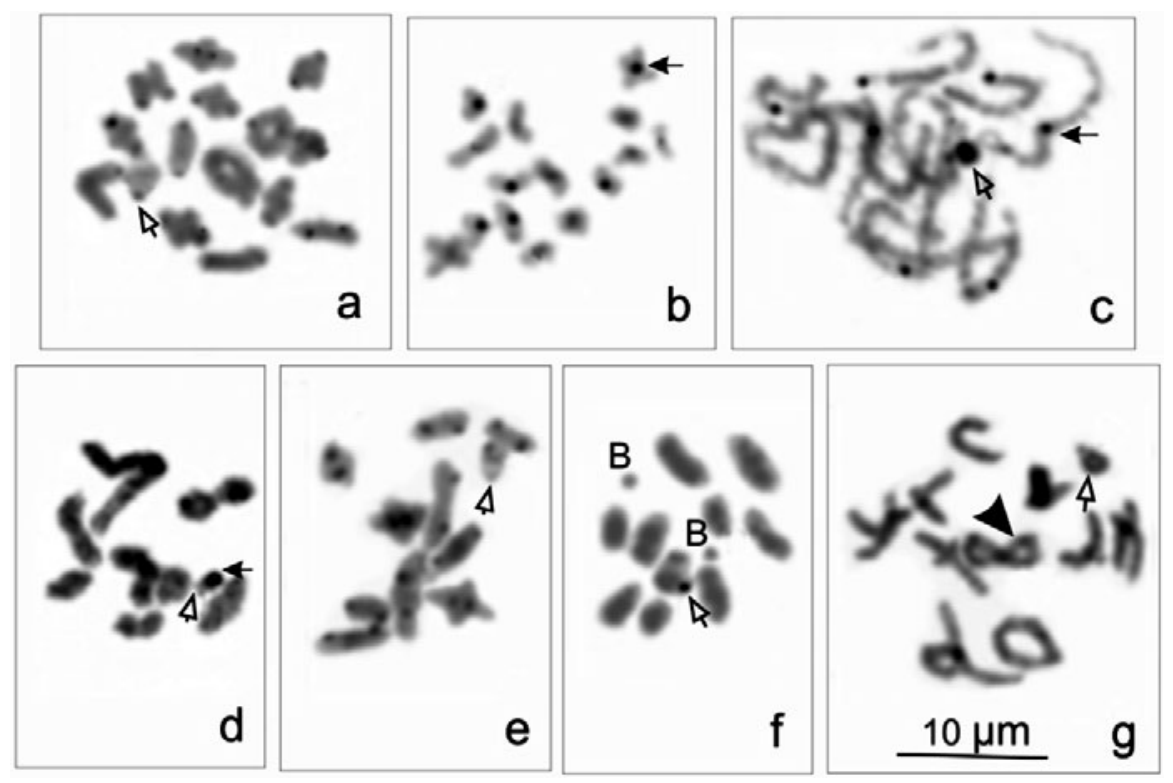

Fig. 2. Meiotic chromosomes after C-band staining. a - diakinesis in Cirrorhynchus kelecsenyi; $\mathrm{b}$ - metaphase II in Cirrorhynchus kelecsenyi; c - pachytene in Dodecastichus inflatus; d - metaphase I in Dodecastichus inflatus; e - diakinesis in Otiorhynchus coecus; f - metaphase I in Otiorhynchus multipunctatus; g - diakinesis in Otiorhynchus morio. Solid arrows indicate C-band blocks, open arrows $\mathrm{Xy}_{\mathrm{p}}$ associations, solid arrowhead the longest bivalent with three chiasmata.

(Figs 2d-g, 3a-c, e-f). One species possesses 14 autosomal bivalents and $\mathrm{Xy}_{\mathrm{p}}$ (Fig. 2a). Examination of diakinesis shows that long autosomal bivalents have either two terminal chiasmata, one terminal and one interstitial chiasma, or only one interstitial or terminal chiasma. Therefore, they form rod-shape figures, crosses and rings (Figs 2a, e-g, 3a-b). An exception is Otiorhynchus morio, with the longest autosomes often forming trichiasmate (two terminal and one interstitial) bivalents (Fig. 2g). Short bivalents of rod morphology are connected by one terminal chiasma. The numbers of bivalents of different shape are not stable, i.e. the same bivalents are sometimes connected by one chiasma and at other times by two chiasmata. The results show that the pattern of meiotic behaviour of the chromosomes is similar for all the beetles examined here.

Cirrorhynchus kelecsenyi $\left(2 \mathrm{n}=30, \mathrm{n} \widehat{0}=14+\mathrm{Xy}_{\mathrm{p}}\right)-$ the karyotype consists of 30 chromosomes of different

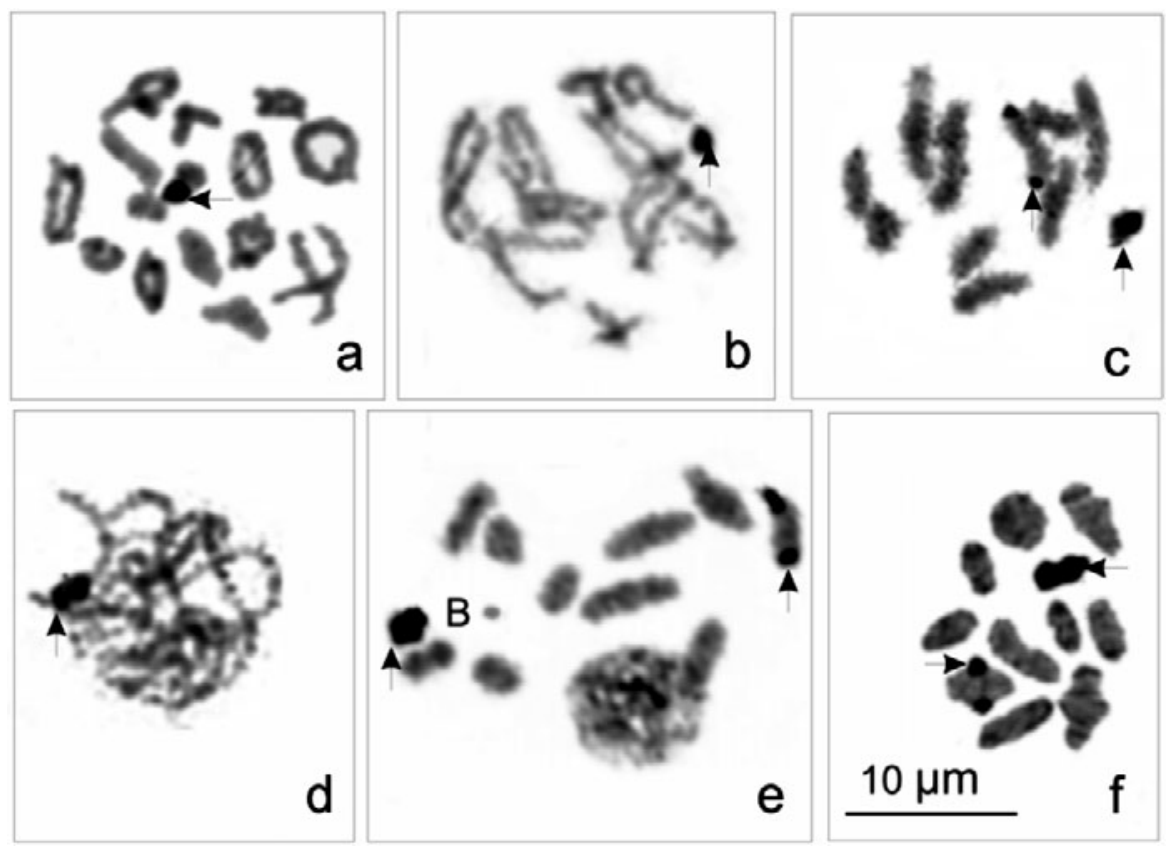

Fig. 3. Spermatocyte nuclei after silver staining. a - diakinesis in Cirrorhynchus kelecsenyi; $\mathrm{b}$ - early diakinesis in Dodecastichus inflatus; c - metaphase I in Otiorhynchus coecus; d - pachytene in Otiorhynchus cornicinus; e - metaphase I in Otiorhynchus multipunctatus; f - metaphase I in Otiorhynchus morio. Arrows show silver impregnation. 
morphology. Three pairs of autosomes are metacentric, two are submetacentric, seven are subtelocentric and two acrocentric. The $\mathrm{X}$ chromosome is metacentric and short (relative length of 5.02\%) while the y chromosome is dotlike $(1.11 \%)$ (Fig. 1a). The two first pairs are the longest with relative lengths of $12.30 \%$ and $11.03 \%$, the remaining autosomes are shorter with $8.48 \%-4.18 \%$ relative length (Table 2). C-positive segments are visible around centromeres in the majority of chromosomes, with the exceptions of the $6^{\text {th }}, 11^{\text {th }}$, and $14^{\text {th }}$ pairs with short, heterochromatic arms. Only the $4^{\text {th }}$ pair is euchromatic, the y chromosome is negatively heteropycnotic (Fig. 2a, b). The argentophilic site is localized on sex chromosomes and is detectable only during meiotic prophase and metaphase I (Fig. 3a). After DAPI staining, bright signals were observed in the centromeric regions (Fig. 4a).

Dodecastichus inflatus $\left(2 \mathrm{n}=22, \mathrm{n} \widehat{\sigma}=10+\mathrm{Xy}_{\mathrm{p}}\right)$ is defined by a symmetric karyotype with a prevalence of metacentric chromosomes and a y chromosome of dotlike shape. The $6^{\text {th }}$ autosomal pair and $\mathrm{X}$ chromosome with a secondary constriction have a subtelocentric morphology, the $10^{\text {th }}$ pair is acrocentric (Fig. 1b). The longest chromosomes include the $1^{\text {st }}-4^{\text {th }}$ pairs of $13.43 \%-10.12 \%$ relative length, whereas the $5^{\text {th }}-10^{\text {th }}$ pairs account for $8.71 \%-4.16 \%$ of the total complement length. The $\mathrm{X}$ chromosome is one of the longest elements with a relative length of $10.67 \%$, while the $\mathrm{y}$ chromosome is the smallest, presenting $1.42 \%$ of the relative length of the entire karyotype (Table 2). In pachytene, short segments of heterochromatin on autosomes are visible but undetectable during mitotic metaphase. Centromeric C-band is distinguishable on the $\mathrm{X}$ chromosome in mitotic stages and also metaphase I. The dot-shaped y chromosome is $\mathrm{C}$-negative (Figs 1b, 2c-d). An $\mathrm{Ag} \mathrm{NO}_{3}$-positive cluster is situated on the sex chromosomes stained during meiotic prophase and metaphase I (Fig. 3b). $\mathrm{CMA}_{3} / \mathrm{DAPI}$ produces homogeneous staining with no bright regions (not shown).

Otiorhynchus coecus $\left(2 \mathrm{n}=22, \mathrm{n} \hat{\sigma}=10+\mathrm{Xy}_{\mathrm{p}}\right)$, karyotype is composed mainly of metacentric chromosomes with the exception of two subtelocentric autosomes $\left(5^{\text {th }}\right.$ pair) and a dot-like y chromosome (Fig. 1c). The relative length of autosomes is $12.52 \%-6.10 \%$, the $\mathrm{X}$ chromosome comprises $11.95 \%$, whereas the y chromosome only $1.24 \%$ (Table 2). Constitutive heterochromatin appears in centromeric regions on all autosomes and the $\mathrm{X}$ chromosome, moreover the latter has two intercalary bands, and autosomes from the $8^{\text {th }}$ pair have one intercalary band (Fig. 1c). Argentophilic blocks are situated on the sex chromosomes and the $4^{\text {th }}$ pair of autosomes, visible from leptotene to metaphase I (Fig. 3c). Only DAPI positive pericentromeric regions were observed (Fig. 4b).

Otiorhynchus cornicinus $\left(2 \mathrm{n}=22, \mathrm{n} \widehat{0}=10+\mathrm{Xy}_{\mathrm{p}}\right)$ has a symmetric karyotype with uniform chromosome mor-
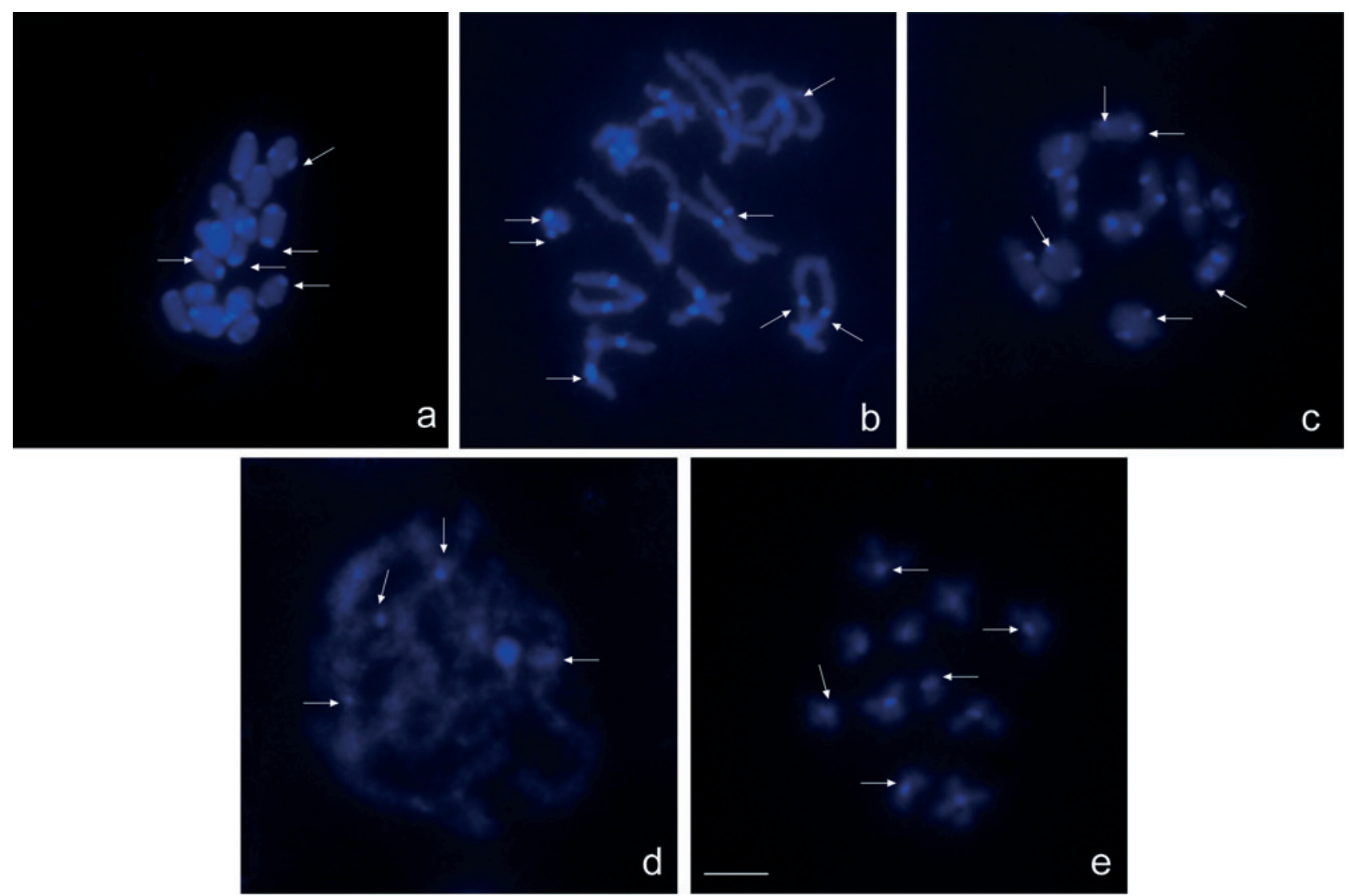

Fig. 4. Chromosomes after DAPI staining. a - metaphase I in Cirrorhynchus kelecsenyi; b - diakinesis in Otiorhynchus coecus; cmetaphase I in Otiorhynchus cornicinus; d - pachytene in Otiorhynchus multipunctatus; e - metaphase II in Otiorhynchus morio. Arrows point to heterochromatic blocks. Scale bar $=5 \mu \mathrm{m}$. 
phology. All autosomes and the $\mathrm{X}$ chromosome have a median centromere and the $\mathrm{y}$ chromosome is dot-like (Fig. 1d). The relative length of the longest chromosomes varies between $12.7 \%-10.13 \%$ (pairs $1-3$ ), the shorter chromosomes are pairs $4-10$ with relative lengths of $9.81 \%-5.63 \%$, the $\mathrm{X}$ chromosome $-8.69 \%$ and $\mathrm{y}-$ $2.06 \%$ (Table 2). The heterochromatin visualized by $\mathrm{C}$-banding is limited to the pericentromeric region of all autosomes and one arm of the $\mathrm{X}$ chromosome (Fig. 1d). From meiotic prophase to metaphase I the sex bivalent was strongly silver stained (Fig. 3d). Only DAPI-positive blocks were detected (Fig. 4c).

Otiorhynchus multipunctatus $(2 \mathrm{n}=22+1-2 \mathrm{~B}, \mathrm{n} \hat{\boldsymbol{\sigma}}=$ $\left.10+\mathrm{Xy}_{\mathrm{p}}+1-2 \mathrm{~B}\right)$. Because there were no good quality plates with mitotic metaphases, its karyotype is described on the basis of metaphase II. The symmetric karyotype contains metacentric autosomes, submetacentric $4^{\text {th }}$ pairand the $\mathrm{X}$ chromosome, the y chromosome is dot-like. On mitotic and meiotic plates 1-2 small additional elements were also visible, probably representing B-chromosomes (Fig. 1e). The sizes of the B-chromosomes are similar to the size of the y chromosome. The relative length of autosomes varies between $11.55 \%-5.08 \%$, the $\mathrm{X}$ chromosome makes up $10.61 \%$ of the karyotype, while the y chromosome $-1.67 \%$, and $2 \mathrm{~B}-3.04 \%$ (Table 2). Observation during metaphase I revealed the presence of heterochromatin only around the centromere of the $\mathrm{X}$ chromosome (Fig. 2f). During meiotic prophase and metaphase I, silver positive regions were located on the sex chromosomes and one pair of autosomes (Fig. 3e). DAPI positive signals were visible only during pachytene (Fig. 4d)

The karyotype of Otiorhynchus morio $\left(2 \mathrm{n}=22\right.$, n $\sigma^{*}=$ $10+\mathrm{Xy}_{\mathrm{p}}$ ) consists of chromosomes of similar length and morphology with median centromeres, only the y chromosome is dot-like (Fig. 1f). Autosome pairs 1-10 make up $13.50 \%-4.85 \%$ of the relative length, the $\mathrm{X}$ chromosome $-9.76 \%$ and the $y$ chromosome $-1.72 \%$ (Table 2 ). All autosomes possess centromeric C-bands of different sizes, whereas a large heterochromatic block occurs on one arm of the $\mathrm{X}$ chromosome in an intercalary position (Fig. 2g). There is argentophilic material on the sex chromosomes and on one pair of autosomes (Fig. 3f). DAPI signals were observed in the centromeric position (Fig. 4e). Weak $\mathrm{CMA}_{3}$ staining labeled one autosomal bivalent (not shown).

\section{DISCUSSION}

Below the chromosomal results for the six species are assessed in order to see whether there is an agreement with the proposed taxonomy. Based on taxonomical characters, the genus Dodecastichus is characterized by the presence of elytra with 12 or 13 striae, and occurs only in Italy, Central and Eastern Europe, and the Balkans. The genus Otiorhynchus is morphologically heterogeneous, has elytra with 10 striae, ventrites without longitudinal furrows, fore and middle tibia not flattened, and femora untoothed or (in some subgenera) the hind femora toothed. Despite the restricted distributions of many endemic species, the genus as a whole is widely distrib- uted throughout the Palaearctic region (Magnano, 1998). The bisexual species from Dodecastichus, Otiorhynchus and Tylotus examined have an identical diploid chromosome number, $2 \mathrm{n}=22$, and meioformula $\mathrm{n} \hat{\boldsymbol{\sigma}}=10+\mathrm{Xy}_{\mathrm{p}}$ (for some species the Xy sex determination system has been described but probably it is mistake because sometimes the "parachute" system is hardly visible on squash preparations) (Table 3). This confirms the karyological conservatism in this weevil group because it is the most characteristic chromosome number of weevils, and probably represents the ancestral state in the Curculionidae family as a whole. All results show that most of the chromosomes are meta- or submetacentric, a condition which is almost the rule in the karyotypic architecture in Otiorhynchini. The karyotype of Otiorhynchus multipunctatus is of some interest because it shows the presence of $\mathrm{B}$ chromosomes, clearly distinguishable from the regular members of the complement. The size of these additional chromosomes is approximately the same as that of the $y$ heterochromosome. Because of the poor knowledge of B-chromosomes in weevils, it is difficult to comment on their genesis. Of the up to 600 species of Curculionidae examined karyologically, only four species have supernumerary chromosomes (Ennis, 1972; Smith \& Brower, 1974; Dey, 1989; Holecová et al., 2005).

The application of the C-banding technique reveals a clear band pattern. C-banded karyotyping is occasionally used for the identification of closely related species in some coleopteran groups, e.g. Carabidae, Aphodiidae, Hydrophilidae, etc., where conventional staining techniques often give insufficient information (Angus et al., 2000; Wilson \& Angus, 2004). In the species examined, the chromosomes resemble one another in having the C-bands restricted mostly to the area around the centromere, which is characteristic of the majority of insects (Juan \& Petitpierre, 1989; Imai, 1991; Rożek, 1998; Almeida et al., 2000; Proença et al., 2002; Zacaro et al., 2004). An intercalary C-band was detected only on two chromosomes of $O$. coecus. On the $\mathrm{X}$ chromosome, the constitutive heterochromatin is located in the centromeric region in all species and also in an intercalary position in $O$. morio and $O$. coecus. In all species examined, the y chromosome does not possess a particular heterochromatic marking, although the C-banding technique does not stain all types of heterochromatin (Sumner, 1990). In Curculionidae, heterochromatin occurs mainly in small proportions and very often when the chromosomes become more condensed during the mitotic metaphase, diakinesis, metaphase I and II, these short segments are weak or are not visible at all (Rożek et al., 2004; Lachowska et al., 2005).

$\mathrm{AgNO}_{3}$ chromosome staining is very useful for the analysis of nucleolar organizer regions (NORs), although this technique mainly reveals transcriptionally active NORs (Sumner, 1990). In beetles, NORs can be located on the autosomal pairs and/or sex chromosomes, although most data show that the nucleolus organizer is widely distributed on one autosomal pair (Moura et al., 2003; Bione et al., 2005). In three of the six species examined two Ag- 
TABLE 3. Overview of the karyotypic data of the bisexual species of Otiorhynchini.

\begin{tabular}{lccc}
\hline Species & $\begin{array}{c}\text { Chromosomal } \\
\text { formula of males }\end{array}$ & $\begin{array}{c}\text { Chromosomal } \\
\text { morphology }\end{array}$ & References \\
\hline
\end{tabular}

Cirrorhynchus kelecsenyi (Frivaldsky, 1892)

Dodecastichus atripes (Apfelbeck, 1918)

Dodecastichus aurosignatus vlasuljensis Apfelbeck, 1894

Dodecastichus dolomitae dryadis (Apfelbeck, 1895) Dodecastichus geniculatus (Germar, 1817)

Dodecastichus inflatus (Gyllenhal, 1834)

Dodecastichus obsoletus (Stierlin, 1861) as D. speiseri Apfelbeck, 1894

Otiorhynchus alpicola Boheman, 1843

Otiorhynchus alpicola atterimus Boheman, 1843

Otiorhynchus apenninus Stierlin, 1883 as O. salicicola Boheman, 1843

Otiorhynchus arcticus (Fabricius, 1780)

Otiorhynchus armadillo (Rossi, 1792)

Otiorhynchus austriacus (Fabricius, 1801)

Otiorhynchus bisulcatus (Fabricius, 1781)

Otiorhynchus carmagnolae (Villa \& Villa, 1835)

Otiorhynchus coecus Germar, 1824 as O. niger (Fabricius, 1775)

Otiorhynchus cornicinus Stierlin, 1861

Otiorhynchus corvus Boheman, 1843

Otiorhynchus croaticus Stierlin, 1861

Otiorhynchus equestris (Richter, 1820)

Otiorhynchus gemmatus (Scopoli, 1763)

Otiorhynchus kollari Gyllenhal, 1834

Otiorhynchus koritnicensis Apfelbeck, 1918

Otiorhynchus meridionalis Gyllenhal, 1834

Otiorhynchus minutesquamosus Solari \& Solari, 1908

Otiorhynchus morio (Fabricius, 1781)

Otiorhynchus multipunctatus (Fabricius, 1792)

Otiorhynchus obsidianus Boheman, 1843

Otiorhynchus obtusus Boheman, 1843

Otiorhynchus opulentus Germar, 1834

Otiorhynchus praecellens bosnarum Stierlin, 1886

Otiorhynchus repletus Boheman, 1843

Otiorhynchus rotifer Apfelbeck, 1828

Otiorhynchus sensitivus (Scopoli, 1763)

Otiorhynchus strumosus Heller, 1897

Otiorhynchus tenebricosus (Herbst, 1784) as O. fuscipes Olivier, 1807

Tylotus chrysops (Herbst, 1797) as Otiorhynchus chrysops Herbst, 1797 metacentric, submetacen-

$2 \mathrm{n}=30, \mathrm{n} \widehat{\widehat{0}}=14+\mathrm{Xy}_{\mathrm{p}}$ tric, subtelocentric, acrocentric, y-dot

$2 \mathrm{n}=22, \mathrm{n} \hat{\sigma}=10+\mathrm{Xy}_{\mathrm{p}} \quad$ metacentric, $\mathrm{y}-\mathrm{dot}$

$2 n=22, n \hat{\sigma}=10+X_{p} \quad$ metacentric, $y-d o t$

metacentric, y-dot

$2 \mathrm{n}=22, \mathrm{n} \widehat{\sigma}=10+\mathrm{Xy}_{\mathrm{p}}$

$2 \mathrm{n}=22, \mathrm{n} \hat{\mathrm{o}}=10+\mathrm{Xy}_{\mathrm{p}}$ metacentric, subtelocen-

tric, acrocentric, y-dot

$2 \mathrm{n}=22, \mathrm{n} \widehat{o}=10+\mathrm{Xy}_{\mathrm{p}} \quad$ metacentric, $\mathrm{y}-\mathrm{dot}$

$2 \mathrm{n}=22, \mathrm{n} \hat{\sigma}=10+\mathrm{Xy}_{\mathrm{p}} \quad$ metacentric, $\mathrm{y}-\mathrm{dot}$

$2 \mathrm{n}=22, \mathrm{n} \hat{\mathrm{O}}=10+\mathrm{Xy}_{\mathrm{p}} \quad$ metacentric, $\mathrm{y}$-dot

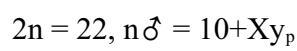

$2 \mathrm{n}=22, \mathrm{n} \hat{\sigma}=10+X \mathrm{y}_{\mathrm{p}}$

$2 \mathrm{n}=22, \mathrm{n} \hat{o}=10+X \mathrm{y}_{\mathrm{p}}$

$2 \mathrm{n}=22, \mathrm{n} \hat{\mathrm{o}}=10+\mathrm{Xy}_{\mathrm{p}}$

$2 \mathrm{n}=22, \mathrm{n} \hat{\sigma}=10+\mathrm{Xy}_{\mathrm{p}}$

$2 \mathrm{n}=22, \mathrm{n} \sigma^{\hat{x}}=10+\mathrm{Xy}$

$2 \mathrm{n}=22, \mathrm{n} \widehat{\widehat{\theta}}=10+\mathrm{Xy}$

metacentric, subtelocentric, y-dot

$2 \mathrm{n}=22, \mathrm{n} \hat{\mathrm{o}}=10+\mathrm{Xy}_{\mathrm{p}} \quad$ metacentric, $\mathrm{y}$-dot

$2 \mathrm{n}=22, \mathrm{n}$ ô $=10+\mathrm{Xy}$

$2 \mathrm{n}=22, \mathrm{n} \hat{\sigma}=10+\mathrm{Xy}_{\mathrm{p}}$

$2 \mathrm{n}=22, \mathrm{n} \hat{\sigma}=10+X \mathrm{y}_{\mathrm{p}}$

$2 \mathrm{n}=22, \mathrm{n} \boldsymbol{o}^{\hat{2}}=10+\mathrm{Xy}_{\mathrm{p}}$

$2 \mathrm{n}=22, \mathrm{n}$ oे $=10+\mathrm{Xy}$

$2 \mathrm{n}=22, \mathrm{n} \hat{\sigma}=10+\mathrm{Xy}_{\mathrm{p}}$

$2 \mathrm{n}=22, \mathrm{n}$ ô $=10+\mathrm{Xy}$

$2 \mathrm{n}=22, \mathrm{n} \widehat{\sigma}=10+\mathrm{Xy}_{\mathrm{p}}$

$2 \mathrm{n}=22, \mathrm{n} \hat{\sigma}=10+X \mathrm{y}_{\mathrm{p}}$

$2 \mathrm{n}=22+1-2 \mathrm{~B}, \mathrm{n} \hat{\mathrm{o}}=$ $10+\mathrm{Xy}_{\mathrm{p}}+1-2 \mathrm{~B}$

$2 \mathrm{n}=22, \mathrm{n} \hat{\sigma}=10+X \mathrm{y}$

$2 \mathrm{n}=22, \mathrm{n} \hat{\sigma}=10+X \mathrm{y}$

$2 \mathrm{n}=22, \mathrm{n} \hat{\sigma}=10+\mathrm{Xy}_{\mathrm{p}}$

metacentric, submetacentric, y-dot

$2 \mathrm{n}=22, \mathrm{n} \hat{\mathrm{O}}=10+\mathrm{Xy}_{\mathrm{p}}$

$2 \mathrm{n}=22, \mathrm{n} \hat{\sigma}=10+X \mathrm{y}$

$2 \mathrm{n}=22, \mathrm{n} \hat{\sigma}=10+\mathrm{Xy}_{\mathrm{p}}$

$2 \mathrm{n}=22, \mathrm{n} \hat{\mathrm{O}}=10+\mathrm{Xy}_{\mathrm{p}}$

$2 \mathrm{n}=22, \mathrm{n} \hat{\sigma}=10+\mathrm{Xy}_{\mathrm{p}}$

$2 \mathrm{n}=22, \mathrm{n}$ ô $=10+X \mathrm{y}$

$2 n=22$

metacentric, $\mathrm{y}$-dot

metacentric, submetacentric, y-dot

metacentric, submetacentric, y-dot

metacentric, submetacentric, y-dot

metacentric, y-dot

metacentric, $\mathrm{y}$-dot

metacentric, y-dot
Present paper

Tucić \& Mesaros, 1992

Tucić \& Mesaros, 1992

Tucić \& Mesaros, 1992

Smith \& Virkki, 1978

Present paper

Tucić \& Mesaros, 1992

Tucić \& Mesaros, 1992

Tucić \& Mesaros, 1992

Smith \& Virkki, 1978

Smith \& Virkki, 1978

Smith \& Virkki, 1978

Smith \& Virkki, 1978

Smith \& Virkki, 1978

Smith \& Virkki, 1978

Lachowska \& Holecová, 2000; Holecová et al., 2002; Present paper

Present paper

Smith \& Virkki, 1978;

Holecová et al., 1997a

Tucić \& Mesaros, 1992

Smith \& Virkki, 1978

Smith \& Virkki, 1978

Smith \& Virkki, 1978

Tucić \& Mesaros, 1992

Smith \& Virkki, 1978

Holecová et al., 1997b

Mikulska, 1960; Holecová et al., 2002; Present paper

Smith \& Virkki, 1978

Present paper

Smith \& Virkki, 1978

Smith \& Virkki, 1978

Lachowska et al., 1998

Tucić \& Mesaros, 1992

Smith \& Virkki, 1978

Tucić \& Mesaros, 1992

Smith \& Virkki, 1978

Tucić \& Mesaros, 1992

Smith \& Virkki, 1978

Smith \& Virkki, 1978 
stained spots occur, one is situated on the sex chromosomes, the second on one pair of autosomes. In meiotic cells of Coleoptera, NOR activity commences at the beginning of the meiotic prophase and disappears in the middle of the diplotene phase. The nucleolar masses produced can persist for a longer time in species with a prolonged diplotene (Virkki et al., 1991; Bione et al., 2005). This phenomenon was observed in all species studied here, but the presence of argentophilic masses on the sex chromosomes up until the late phase of meiosis I may indicate that $\mathrm{Xy}_{\mathrm{p}}$ association is not necessarily due to an NOR. Studies on the segregation of sex chromosomes in curculionids showed that, even when the NORs are autosomal, the lumen of the sex bivalent is filled with a proteinaceous substance with an affinity for silver from diakinesis to anaphase I. It is suggested that this substance may play an adhesive role, controlling the correct separation (Virkki et al., 1991; Moura et al., 2003; Bione et al., 2005). Because in the other three species only one NOR occurs on the autosomes, our data appears in accordance with the hypothesis that an autosome pair functions as a nucleolus organizer, and the presence of nonnucleolar argyrophilous substances in the $\mathrm{Xy}_{\mathrm{p}}$ bivalents contributes to regular association and segregation during meiosis. However, only the employment of fluorescent in situ hybridization with an rDNA probe would precisely identify the NORs in these species.

Chromosome staining by DNA base specific fluorochromes is little used in cytogenetic studies of Coleoptera (Vitturi et al., 1999; Colomba et al., 2006; Moura et al., 2003; Schneider et al., 2006) and has never hitherto been applied to Curculionidae. The use of fluorescent DNAbanding dyes with different specificities gives a better characterization of heterochromatic regions in terms of their relative enrichment with $\mathrm{A}-\mathrm{T}$ or $\mathrm{G}-\mathrm{C}$ base pairs. In the species of Otiorhynchus studied C-bands fluoresced brightly after DAPI staining suggesting the occurrence of a high amount of $\mathrm{A}-\mathrm{T}$ base pairs in the DNA sequences making up the heterochromatic C-bands. Some differences in fluorescent intensity could be explained by the degree of condensation, i.e. the more the chromosomes are elongated, the weaker the visible signals. The sequential $\mathrm{CMA}_{3}$ staining of chromosomes of the Otiorhynchus species studied showed that heterochromatin is negatively stained by chromomycine, which supports the hypothesis that there is an abundance of $\mathrm{A}-\mathrm{T}$ in heterochromatin. The fluorochrome $\mathrm{CMA}_{3}$ staining labels NORs independently of their activity, and the fluorescence is associated with $\mathrm{G}-\mathrm{C}$ content typical of genes coding for ribosomal RNA (rDNA) (Anokhin \& Nokkala, 2004). The correlation between $\mathrm{CMA}_{3}$ bands and NORs is quite common in insects (Brito et al., 2003). However, a weak fluorescence after $\mathrm{CMA}_{3}$ application, possibly coincident with NORs, was visible only in $O$. morio. The lack of positive signals in other species may suggest a small number of rDNA genes; alternatively, the absence of $\mathrm{CMA}_{3}$ bands may be due to technical reasons because sometimes this band disappears when $\mathrm{C}$ banding is applied before sequential staining with chromomycine (Brito et al., 2003).
The taxonomic position of Cirrorhynchus kelecsenyi has changed. Previously it was included within the genus Otiorhynchus (Stierlin, 1883; Reitter, 1916; Winkler, 1932), but later it was put in a separate genus, Cirrorhynchus because it has elythra with 10 striae, ventrites without longitudinal furrows, and male tibia hollowed, the hind one with a long fringe of hair along the inner edge. The male ventrite 5 is characterized by two long tufts of hairs pointing forward on hind edge. The distribution of the genus is very limited (Italy, Slovakia, Hungary and Balkans) (Magnano, 1998). The karyotype of $C$. kelecsenyi consists of 30 chromosomes and differs strikingly from that in all other Otiorhynchini species examined, not only because of its higher chromosome number but also due to its asymmetry of chromosome sizes and existence of acrocentric chromosomes with short heterochromatic arms (Table 3). The increased number of small acrocentric chromosomes support the suggestion that the karyotypic evolution in this species was achieved by centric fissions of the ancestral metacentric chromosomes. Also the sex bivalent is smaller than in the species of the two other genera. The present karyological study supports the results of the taxonomical revision of this group made by Magnano (1998). According to the karyological data Otiorhynchus and Dodecastichus are closely related genera, whereas Cirrorhynchus is a distinct taxon.

ACKNOWLEDGMENTS. This research was supported by the Polish Ministry of Science and Information Society Technologies, grant no. 3P04C 08525 to D. Lachowska and VEGA (Scientific Grant Agency of the Ministry of Education and the Slovak Academy of Sciences), grant no. 1/3277/06 to M. Holecová.

\section{REFERENCES}

Almeida M.C., Zacaro D.M. \& Cella D.M. 2000: Cytogenetics analysis of Epicauta atomaria (Meloidae) and Palembus dermestoides (Tenebrionidae) with Xyp sex dtermination system using standard staining, C-bands, NOR and synaptonemal complex microspreading techniques. Hereditas 133: $147-157$.

Angus R.B., Brown R.E. \& Bryant L.J. 2000: Chromosomes and identification of the sibling species Pterostichus nigrita (Paykull) and P. rhaeticus Heer (Coleoptera: Carabidae). System. Entomol. 25: 325-337.

Anokhin B. \& Nokkala S. 2004: Characterization of C-heterochromatin in four species of Hydrozoa (Cnidaria) by sequence specific fluorochromes Chromomycin $\mathrm{A}_{3}$ and DAPI. Caryologia 57: 163-166.

ARNoldi L.V. 1975: [Weevils of the genus Otiorhynchus Germar (Coleoptera, Curculionidae) of Mongolia and of adjacent regions of the USSR.] In: Insects of Mongolia. Vol. 6. Nauka, pp. 254-284 [in Russian].

Bione E., Camparoto M.L. \& Simoes Z.L. 2005: A study of constitutive heterochromatin and nucleolus organizer regions of Isocopris inhiata and Diabroctis mimas (Coleoptera: Scarabaeidae, Scarabaeinae) using C-banding, $\mathrm{AgNO}_{3}$ staining and FISH techniques. Gen. Mol. Biol. 28: 111-116.

Brito R.M., Caixerio A.P., Pompolo S.G. \& Azevedo G.G. 2003: Cytogenetic data of Portamona peckoli (Hymenoptera, Apidae, Meliponini) by $\mathrm{C}$ banding and fluorochrome staining

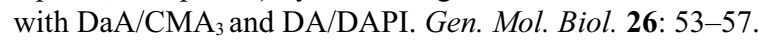


Colomba M.S., Vitturi R., Libertini A., Gregorini A. \& Zunino M. 2006: Heterochromatin of the scrab beetle, Bubas bison (Coleoptera: Scarabaeidae) II. Evidence for AT-rich compartmentalization and a high amount of rDNA copies. Micron 37: $47-51$.

Dey S.K. 1989: B-chromosomes in two species of Indian weevils (Coleoptera: Curculionidae). Cytobios 57: 15-18.

Dieckmann L 1980: Beiträge zur Insektenfauna der DDR: Coleoptera - Curculionidae (Brachycerinae, Otiorhynchinae, Brachyderinae). Beitr. Entomol. (Berlin) 30: 145-310.

Donlon T.A. \& Magenis R.E. 1983: Methyl green is a substitute for distamycin $\mathrm{A}$ in the formation of distamycinA/DAPI C-bands. Hum. Genet. 65: 144-146.

DutTon L.A. \& Angus R.B. 2007: A karyosystematic investigations of a group of sibling species related to Stictotarsus griseostratus (De Geer) (Coleoptera: Dytyscidae). Comp. Cytogenet. 1: 3-16.

ENNIS T.J. 1972: Low chromosome number and post reductional $\mathrm{X} 0$ in Gelus californicus (Lec.) (Coleoptera: Curculionidae). Can. J. Genet. Cytol. 14: 851-857.

Gómez-Zurita J., Pons J. \& Petitpierre E. 2004: The evolutionary origin of a novel karyotype in Timarcha (Coleoptera, Chrysomelidae). J. Zool. Syst. Evol. Res. 42: 332-341.

Holecová M., RożeK M. \& LachowsKa D. 1997a: C-banded karyotype of Otiorhynchus corvus Boheman 1843 (Coleoptera, Curculionidae). Cytologia 62: 209-212.

Holecová M., RożeK M. \& LaChowsKa D. 1997b: Karyological notes on four weevil species from Sicily (Coleoptera, Curculionidae). Acta Zool. Univ. Comen. 41: 25-31.

Holecová M., Rożé M. \& LachowsKa D. 2002: Heterochromatic banding patterns on chromosomes of twelve weevil species (Insecta, Coleoptera, Curculionoidea: Apionidae, Curculionidae). Folia Biol. (Kraków) 50: 129-134.

Holecová M., RożeK M. \& LachowsKa D. 2005: Evidence of B-chromosomes in thekaryotype of Barypeithes pellucidus Boheman 1834 (Coleoptera, Curculionidae, Entiminae) from Central Europe. Folia Biol. (Kraków) 53: 65-68.

Howell W. \& Black D.A. 1980: Controlled silver-staining of nucleolus organizer regions with protective colloidal developer: a 1-step method. Experientia 36: 1014-1015.

Hsiao C. \& Hsiao T.H. 1984: Cytogenetic studies of alfalfa weevil (Hypera postica) strains (Coleoptera: Curculionidae). Can. J. Genet. Cytol. 26: 348-353.

IMAI T.H. 1991: Mutability of constitutive heterochromatin (C-bands) during eukaryotic chromosomal evolution and their cytological meaning. Jpn. J. Genet. 66: 635-661.

Juan C. \& Petitpierre E. 1989: C-banding and DNA content in seven species of Tenebrionidae (Coleoptera). Genome 32: 834-839.

Lachowska D. \& Holecová M. 2000: Karyological investigations on seven weevil species (Coleoptera, Curculionidae). Folia Biol. (Kraków) 48: 111-114.

Lachowska D., Holecová M. \& RożeK M. 1998: Karyotypic data on weevils (Coleoptera, Curculionidae). Folia Biol. (Kraków) 46: 129-136.

LaChowsKa D., Holecová M. \& RożEK M. 2004: Notes on chromosome numbers and C-banding pattern in karyotypes of some weevils from Central Europe (Coleoptera, Curculionoidea: Apionidae, Nanophyidae, Curculionidae). Folia Biol. (Kraków) 52: 61-66.

LachowsKa D., Holecová M. \& RożeK M. 2005: C-banding karyotype and NORs analyse in eight species of Barypeithes Duval from Central Europe (Coleoptera, Curculionidae, Entiminae). Caryologia 58: 274-280.
Lachowska D., Holecová M. \& RożeK M. 2006a: Cytogenetic differences between Peritelus familiaris and Centricnemus leucogrammus (Coleoptera: Curculionidae: Entiminae: Peritelini). Eur. J. Entomol. 103: 687-690.

LachowsKa D., Holecová M. \& RożeK M. 2006b: Karyotypic characterization of three weevil species (Coleoptera: Curculionidae, Brachyderini). Folia Biol. (Kraków) 54: 13-17.

LaWrence J.F. \& Newton A.F. 1995: Families and subfamilies of Coleoptera (with selected genera, notes, references and data on family-group names). In Pakaluk J. \& Ślipiński S.A. (eds): Biology, Phylogeny, and Classification of Coleoptera. Muzeum i Instytut Zoologii, PAN, Warszawa, pp. 559-1092.

Levan A., Fredga K. \& Sonberg A. 1964: Nomenclature for centromeric position on chromosomes. Hereditas 52: 201-220.

Magnano L. 1998: Notes on the Otiorhynchus Germar, 1824 complex (Coleoptera: Curculionidae). In Colonelli E., Low S. \& Osella G. (eds): Taxonomy, Ecology and Distribution of Curculionoidea. XX I.C.E. (1996, Fizerze, Italy). Mus. Reg. Sci. Nat., Torino, pp. 51-80.

MiKULSKA I. 1951: The chromosome number in Otiorhynchus salicis Ström (Curculionidae, Coleoptera) in Poland. Bull. Acad. Pol. Sci. Lett. 150: 269-276.

MikUlsKa I. 1960: New data to the cytology of the genus Otiorhynchus Germ. (Curculionidae, Coleoptera) from Poland. Cytologia 25: 322-333.

Moura R.C, Souza M.J., Melo N.F. \& Lira-Neto A.C. 2003: Karyotypic characterization of representatives from Melolonthinae (Coleoptera: Scarabaeidae): karyotypic analysis, banding and fluorescent in situ hybridization (FISH). Hereditas 138: 200-206.

Penecke K. 1935: Neubeschreibungen, kritische Darlegungen und kurze Mitteilungen überpaläarktische Curculioniden. Koleopt. Rdsch. (Wien) 21: 93-112.

Petitpierre E., Kippenberg H., Mikhailov Y. \& Bourdonne J.C. 2004: Karyology and cytotaxonomy of the genus Chrysolina Motschulsky (Coleoptera, Chrysomelidae). Zool. Anz. 242: 347-352.

Proença S.J.R., Serrano A.R.M. \& Collares-Pereira M.J. 2002: Cytogenetic variability in genus Odontocheila (Coleoptera, Cicindelidae): karyotypes, C-banding, NORs and localization of ribosomal genes of $\mathrm{O}$. confuse and $\mathrm{O}$. nodicornis. Genetica 114: 237-245.

ReitTer E. 1916: Fauna Germanica V. K.G. Lutz, Stuttgart, 343 $\mathrm{pp}$.

RożEK M. 1994: A new chromosome preparation technique for Coleoptera (Insecta). Chromos. Res. 2: 76-78.

RożEK M. 1998: C-bands and NORs on chromosomes of Bembidion lampros (Herbst.) and Bembidion properans (Steph.) (Coleoptera, Carabidae). Cytologia 63: 317-321.

RożEK M. \& LACHowsKa D. 2001: C-bands on chromosomes of four beetle species (Coleoptera: Carabidae, Silphidae, Elateridae, Scarabaeidae). Folia Biol. (Kraków) 49: 179-182.

Rożek M., Lachowska D., Petitpierre E. \& Holecová M. 2004: C-bands on chromosomes of 32 beetle species (Coleoptera: Elateridae, Cantharidae, Oedemeridae, Cerambycidae, Chrysomelidae and Curculionidae). Hereditas 140: 1-10.

Schneider M.C., Almeida M.C., Rosa S.P., Costa C. \& Cella D.M. 2006: Evolutionary chromosomal differentiation among four species of Conoderus Eschscholtz, 1829 (Coleoptera, Elateridae, Agrypninae, Conoderini) detected by standard staining, C-banding, silver nitrate impregnation, and $\mathrm{CMA}_{3} / \mathrm{DA} / \mathrm{DAPI}$ staining. Genetica 128: 333-346.

SCHWEIZER D. 1976: Reverse fluorescent chromosome banding with chromomycin and DAPI. Chromosoma 58: 307-324. 
Smith S.G. \& Brower J.H. 1974: Chromosome numbers of stored-product Coleoptera. J. Kans. Entomol. Soc. 47: 317-319.

Smith S.G. \& VirkKi N. 1978: Animal Cytogenetics. Insecta 3. Coleoptera 5. Gebrüder Borntraeger, Berlin, 366 pp.

SMreCZyŃski S. 1966: Weevils - Curculionidae. Subfamilies Otiorhynchinae, Brachyderinae. Keys for identification of Polish insects. PWN, Warszawa, 130 pp. [in Polish].

STIERLIN G. 1883: Bestimmungstabellen der europäischer Coleopteren. IX Curculionidae. Mitt. Schweiz. Entomol. Ges., Schaffhausen 6: 403-645.

SumNer A. 1972: A simple technique for demonstrating centromeric heterochromatin. Exp. Cell. Res. 75: 304-306.

Sumner A. 1990: Chromosome Banding. Unwin \& Hyman, London, xiv $+434 \mathrm{pp}$.

Suomalinen E. 1947: Parthenogenese und polyploidie bei Rüssalkäfren (Curculionidae). Hereditas 33: 425-456.

Suomalainen E., Saura A. \& LoKki J. 1987: Cytology and evolution in parthenogenesis. CRC Press, Boca Raton, FL, 232 pp.
Tucić B. \& Mesaroš G. 1992: Chromosome counts in some high altitude Otiorhynchus Germ. species from Yugoslavia. Caryologia 45: 213-219.

Virkki N., Mazzella C. \& Denton A. 1991: Silver staining of the coleopteran $\mathrm{Xy}_{\mathrm{p}}$ sex bivalent. Cytobios 67: 45-63.

Vitturi R., Colomba M.S., Barbieri R. \& Zunino M. 1999: Ribosomal DNA location in the scrab beetle Thorectes intermedius (Costa) (Coleoptera: Geotrupidae) using banding and fluorescent in situ hybridization. Chromos. Res. 7: 255-260.

WiLSON C.J. \& ANGUS R.B. 2004: A chromosomal analysis of the west European species of Aphodius Illiger, subgenus Aphodius s. str. (Coleoptera: Aphodiidae). Tijdschr. Entomol. 147: 259-264.

Winkler A. 1932: Catalogus Coleopterorum Regionis Palaearcticae. Pars 12. Wien, pp. 1393-1520.

Zacaro A.A., Proença S.J.R., Lopes-Andrade C. \& Serrano A.R.M. 2004: Cytogenetic analysis of Ctenostomini by $\mathrm{C}$-banding and rDNA localization and its relevance to the knowledge of the evolution of tiger beetles (Coleoptera: Cicindelidae). Genetica 122: 261-268.

Received October 3, 2007; revised and accepted November 20, 2007 